\title{
THE MISSILE GUIDANCE ESTIMATION USING EXTENDED KALMAN FILTER-UNKNOWN INPUT-WITHOUT DIRECT FEEDTHROUGH (EKF-UI-WDF) METHOD
}

\author{
SubChan $^{1}$ AND TAhiYATUl Asfihani ${ }^{2}$ \\ ${ }^{1}$ Institut Teknologi Sepuluh Nopember Sukolilo, Surabaya, \\ subchan@matematika.its.ac.id \\ ${ }^{2}$ Institut Teknologi Sepuluh Nopember Sukolilo, Surabaya, \\ tahiyatul.asfihani@gmail.com
}

\begin{abstract}
This paper consider the estimation of the optimal missile guidance which the objective is to minimize the interception time and the energy expenditure. The proposed Extended Kalman Filter-Unknown Input-Without Direct Feedthrough (EKF-UI-WDF) approach is to estimate the optimal missile guidance and the target acceleration as unknown input to the missile-target interception model. Unknown input is any type of signals without prior information from a given state model or a measurement. The computational for the EKF-UI-WDF method and optimal missile guidance show the closest range to the missile-target is smaller than using the EKF. However the Mean Squared Error (MSE) of estimating the optimal missile guidance using EKF method is smaller than using EKF-UI-WDF method.

Key words and Phrases:EKF-UI-WDF, unknown input, optimal control, missile, target.
\end{abstract}

